\title{
Tecnologias da comunicação: \\ knock-out na propaganda?
}

\section{Goiamérico Felício Carneiro dos Santos*}

\begin{abstract}
Resumo
A emergência de novos espaços e de novos mercados, em face da configuração do mundo contemporâneo, vem transformando conceitos e estratégias econômicas, forçando um novo modus vivendi, um novo modus operandi. Partindo da constatação de que as novas tecnologias da comunicação produziram um impacto no negócio da propaganda, caberia, então, interrogar: estarão os profissionais da publicidade aptos a desempenhar o seu papel, na perspectiva do webmarketing? Esse é o ponto de partida das considerações preliminares apresentadas neste texto. O objetivo é refletir acerca das dificuldades enfrentadas, hoje, pelas agências de publicidade, bem como sobre o seu papel e a sua competência diante dos novos desafios impostos pela desterritorialização da economia e pelas novas ferramentas e novas linguagens que vêm movimentando o mundo dos negócios, da publicidade e do marketing.

Palavras-chave: tecnologias da comunicação, marketing digital, publicidade e propaganda.
\end{abstract}

Você sempre pergunta pelas novidades daqui desse sertão, e finalmente posso lhe contar uma importante.

Fique o compadre sabendo que agora temos aqui uma máquina imponente, que está entusiasmando todo mundo. A máquina extraviada - José J. Veiga

Na epígrafe acima, presumimos ter mais que um bom mote para uma tentativa de abordagem acerca das impactantes transformações às quais o negócio da propaganda se vê sujeitado na

* Dr. em Letras e prof. do curso de Publicidade e Propaganda e Coordenador de Pós-Graduação (Lato Sensu) em Assessoria em Comunicação da Faculdade de Comunicação e Biblioteconomia da Universidade Federal de Goiás.

Comun. Inf., v. 6, n. 1, p.11-29, jan./jun. 2003 


\section{2}

contemporaneidade. O que nos sugere uma possível interpretação do conto de José J. Veiga', bem pode ser uma atualização crítica do "Bezerro de Ouro" dos nossos tempos: uma máquina extraviada para uma longínqua e qualquer cidadezinha de um pacato interior. Uma máquina que chega de inopino causando, mais que simples curiosidade, um misto de fascínio, mistério e medo.

Uma máquina que não diz a que veio, mas que aglutina em torno de si todos os interesses, toda veneração, inclusive por parte daqueles que se tornam suas vítimas. Uma máquina para a qual os intrigados habitantes deste planeta devotam toda adoração, mesmo não tendo noção da sua utilidade e dos seus poderes. Talvez venha mesmo do não-entendimento, do mistério, essa adoração, essa aura de magia que os moradores da narrativa impregnam à máquina-totem. Esse novo "Bezerro de Ouro", causa de fascínio que provocou tanto impacto, tantos rumores e rebuliços; esse ídolo de ferro e engrenagens devoradoras que também trouxe novos ânimos, novas atmosferas de vida, despertando o imaginário entre as personagens da narrativa não pode trazer, qual a esfinge devoradora à porta de Tebas, uma terrível ameaça? Essa esfingica máquina não nos remete às prédicas do segundo mandamento das sagradas escrituras que não só proíbe a idolatria como também nos adverte quanto ao fabrico de imagens e estátuas?

A abordagem dessa questão acaba por nos remeter à interrogação de Pierre Lévy, inaugurando a discussão acerca da Cibercultura": "As tecnologias têm um impacto?" Uma pergunta que soa como mero exercício retórico, na medida em que Lévy é enfático ao afirmar:

Nos textos que anunciam colóquios, nos resumos dos estudos oficiais ou nos artigos da imprensa sobre o desenvolvimento da multimídia, fala-se muitas vezes no 'impacto das novas tecnologias da informação sobre a sociedade ou a cultura. A tecnologia seria algo comparável a um projétil (pedra, obus, míssil?) e a cultura ou a sociedade, um alvo vivo $^{3}$.

Com efeito, vislumbrar o impacto das novas tecnologias em nossa cultura como algo mera e tão - somente destruidor significa assumir uma postura generalizante e apressada. Mais que isso, essa visão apocalíptica acaba mesmo denunciando uma percepção distorcida e rancorosa por parte daqueles que têm dificuldade para aceitar o novo, com a coragem necessária para encarar novos desafios. Nas palavras nada apaziguadoras de Lévy, os adeptos da teoria das catástrofes produzidas pelas novas tecnologias parecem se esquecer que as

Comun. Inf., v. 6, n. 1, p.11-29, jan./jun. 2003 
máquinas são frutos da invenção humana. Elas são o resultado do desenvolvimento da técnica dos homens que, cada vez mais, intensificam os seus exercícios de imaginação e criatividade exatamente para superar os limites que lhes são impostos. Já não dá para continuar ignorando aquilo que é hoje óbvio aos nossos olhos: a técnica, da qual resultam os "catastróficos" artefatos tecnológicos, constitui-se na própria cultura do homem.

Daí torna-se necessário, sim, deixarmos de adorar esses novos "Bezerros de Ouro" como objetos da nossa eterna adoração para devotarmos ao próprio homem o alvo do nosso encanto. Afinal, a máquina, os artefatos tecnológicos significam mais que um produto da fértil imaginação do homem. Essas invenções resultam da poderosa capacidade criativa dos filhos de Prometeu. Continuar criando novas soluções, novos meios de se colocar à prova a imperiosa necessidade de romper os limites impostos à raça humana, sempre predisposta aos mais tenazes desafios, constitui-se mesmo como uma sina, um destino do qual não se pode, não se quer fugir.

Certo é que toda e qualquer invenção sempre nos traz em seus inúmeros resultados previstos o imprevisível, as surpresas às vezes agradáveis, às vezes nem tanto. Afinal, o que disse o vate Mallarmé acerca do imponderável na criação poética (no plano literário), vale também para qualquer outra criação do homem que, tanto quanto um poema, exige um domínio técnico cada vez mais requintado: "Um lance de dados jamais abolirá o acaso". Sem dúvida, impactos as tecnologias provocam e sempre provocaram. Torna-se mister dizer, mesmo que tal afirmação nos seja bastante dura e desconfortável, que esses impactos tornam-se mesmo inevitáveis - desejáveis, até-pelo simples e salutar fato de que eles introduzem novos paradigmas, novas perspectivas, novas possibilidades de realizações aos sempre inquietos homens dotados da energuéia, tão característica do espírito do homem grego. Essa impactante tecnologia, por ser inevitável, torna-se desejável, apesar de que toda e qualquer nova tecnologia acaba por produzir em suas trajetórias uma nefasta galeria de vencidos e perdedores. Isso porque, não sabendo interpretar a nova linguagem que advém das novas tecnologias, os vitimados acabam por ceder aos caprichos da temível esfinge, sempre desafiadora, fazendo voltar contra os incautos o seu enigma que se transforma em verdadeiras armadilhas: "Decifra-me ou devoro-te!".

Assim, não há como deixar de admitir que as tecnologias provocam impactos que se alastram como uma onda de choques, devastando,

Comun. Inf., v. 6, n. 1, p.11-29, jan./jun. 2003 


\section{4}

devorando aqueles que são ineptos para assimilar os novos conceitos, as novas linguagens com as quais o homem passa a operacionalizar o seu mundo. Porque não basta aprender a lidar com a máquina. Não basta saber, por exemplo, manusear programas de computador. Mais que isso, é necessário aprender com as novas máquinas, os novos artefatos tecnológicos, faz-se necessário estabelecer uma nova relação com o mundo. E preciso entender que as técnicas e os artefatos tecnológicos podem significar, antes de tudo, causa e conseqüência de um novo vislumbre do mundo. Uma nova forma de se entender o mundo, de relacionar-se com o meio que tem nas novas tecnologias uma visibilidade intensa.

Pierre Lévy, ao fazer referência a uma das principais linhas de pesquisa do empreendimento midialógico de Régis Debray, propõe que se questione: "Como é possível que formas institucionais e técnicas materiais transmitam idéias... e vice-versa? ${ }^{4}$, ao mesmo tempo em que pondera que a crítica está sendo dirigida a quem não teria que assumir a culpa. Seria, a partir de agora, por demais ingênuo questionar as relações estabelecidas pela tecnologia causadora de efeitos sofridos por uma dada cultura. Para Lévy, a verdadeira causa está num "grande número de atores humanos que inventam, produzem, utilizam e interpretam de diferentes formas as técnicas"s.

Separar o humano de seu ambiente material, assim como dos signos e das imagens por meio dos quais ele atribui sentido à vida e ao mundo. Da mesma forma, não podemos separar o mundo material - menos ainda sua parte artificial - das idéias por meio das quais os objetos técnicos são concebidos e utilizados nem dos humanos que os inventam, produzem e utilizam. Acrescentemos, enfim, que as imagens, as palavras, as construções de linguagem entranham-se nas almas humanas, fornecem meios e razões de viver aos homens e suas instituições, são recicladas por grupos organizados e instrumentalizados, como também por circuitos de comunicação e memórias artificiais ${ }^{6}$.

Concordemos, ainda que seja desconfortável, até porque perante aos olhos de muitos negar tal fato soa como algo politicamente incorreto, que as tecnologias trazem em seu bojo um impacto. Sim. A tecnologia digital é devastadora como todas as tecnologias o foram. Até porque a história nos mostra que nem todos são incluídos na mesma ordem e na mesma proporção que aqueles mais afortunados que conseguem decifrar, ao menos em parte e por breve interregno de tempo, as novas esfinges que o gênio humano vem engendrando em sua longa ocupação do planeta terra.

Comun. Inf., v. 6, n. 1, p.11-29, jan./jun. 2003 
Basta ver o fenômeno provocado pelo surgimento da escrita entre os gregos. Há um consenso entre os estudiosos mais experimentados que 700 a. C. constitui-se numa data aproximada do surgimento da escrita entre os gregos. Até essa presumida data, os gregos consolidaram toda uma vasta e riquíssima cultura no plano da oralidade. Os passados, as tradições, eram recordados pelos velhos que tinham a incumbência de guardar na memória toda uma riqueza para que elas fossem repassadas às futuras gerações.

Em seu próprio tempo, esses poetas [líricos] não eram lidos, mas ouvidos. Para alcançar, em qualquer medida, o que chamamos de 'publicação', suas obras deviam ser executadas, perante audiências grandes ou pequenas - e, muitas vezes, também pela respectiva audiência, que se tornava participante, como acontecia no caso das cantigas de trabalho e das canções de dançar. A fama do compositor, muitas vezes evocada com riqueza, tinha nessa circunstância o seu único fundamento. Já os poetas letrados podem dispensar a expressão de um desejo apaixonado de fama, pois seus editores cuidam disso para eles-e seus críticos também? ${ }^{7}$.

Com o estabelecimento da escrita na cultura grega, portanto, verificou-se uma enorme cisão entre aquela gente. Uma enorme fratura cultural que provocou graves conseqüências culturais. A partir desse fato, passamos a ter, de um lado, os "letrados" e, de outro, os "préletrados e os "não - letrados". Não perceberam eles, naquele momento, o nefasto acontecimento que tal fato ocasionaria. Até mesmo porque os gregos da Grande Época Clássica, no tempo de Péricles e dos três grandes tragediógrafos - Hesíodo, Sófocles e Euripedes -, não tinham nítido qualquer termo correspondente a letrado, iletrado, pré-letrado. Eles tinham a concepção de pessoas musicais e não - musicais, sendo educadas aquelas e despossuídas de educação estas. Os romanos, sim, elaboraram o conceito de litteratus, para o homem de letras, que lê, e para o que não lê, "illitteratus".

Nessa cisão, fortaleceram-se os que detinham o domínio da nova tecnologia. Os gregos não inventaram simplesmente um alfabeto. Eles inventaram uma nova cultura, uma nova forma de relacionamento com o mundo. Nesse momento, a memória desvencilha-se do corpo. A retórica, o poder de convencimento ficou com os letrados, os incluídos na nova cultura. A palavra escrita passou a significar, ao mesmo tempo, libertação e aprisionamento. Dominantes e dominados passaram a conviver numa relação cada vez mais desigual, cada vez mais injusta.

Comun. Inf., v. 6, n. 1, p.11-29, jan./jun. 2003 


\section{6}

Para os primeiros, os privilégios que tal domínio tecnológico possibilitava. Enquanto isso, os iletrados passaram a ter a palavra se insurgindo contra as suas próprias vidas. A palavra tinha, então, a aura do encanto, do espírito que tudo vê e tudo pode.

O impacto dessa devastadora tecnologia da escrita acabou mesmo impondo a estagnação de toda a cultura grega, que ficou circunscrita aos papiros, aos textos que paralisaram uma cultura construída à força de uma gigantesca imaginação que ainda não conseguia racionalizar o mundo e os desconcertos do mundo. A par disso, todo o fascínio que nos causa aquela portentosa cultura grega nos foi legado pelos textos épicos de Homero, pelas criações dos líricos (Píndaro, Arquíloco e Safo) e dos três grandes trágicos (Ésquilo, Sófocles e Eurípedes) e que registrados pelos copistas, a mando de Péricles.

Quanto infortúnio, quanta desdita não provocou a tecnologia da escrita? Quanta tragédia, além da sofrida pelos gregos, não ocorreu devido a uma fratura estabelecida entre dois mundos! À distância, vemos como algo pitoresco os fatos ocorridos, nos quais os escravos da ignorância textual escrita sofreram pavores e castigos. A palavra escrita, assim como a palavra oral dominada pelo poder discursivo dos antigos retóricos gregos, delineou mais fortemente a constituição de mais uma arma a ser utilizada como constituição e perpetuação do poder entre os homens.

Em sua longa e profícua discussão acerca da estética da recepção que se dá por meio da interpretação e dos seus limites, Umberto Eco nos dá conta de um fato revelador da insurgência da escrita entre os nativos do novo mundo descoberto e colonizado pelos ingleses. Um acontecimento que seria cômico, não fosse a revelação de uma tragédia perpetuada através dos tempos que vem escravizando os iletrados. $\mathrm{O}$ relato que nos apresenta Eco é da lavra do Bispo John Wilkins e data de 1641:

“É - nos dado avaliar quão estranha possa ter parecido a arte da escrita quando de sua primeira invenção por aqueles americanos recentemente descobertos que se surpreendiam vendo os homens os homens conversarem com os livros e acreditavam piamente que o papel pudesse falar...

"Existe, a propósito, um bonito conto a respeito de um escravo índio; o qual, enviado por seu dono com um cesto de figos e

Comun. Inf., v. 6, n. 1, p.11-29, jan./jun. 2003 
uma carta, comeu, ao longo do caminho, grande parte de sua carga, entregando o resto à pessoa a quem era dirigida; a qual, ao ler a carta, e não encontrando a quantidade de figos correspondente ao que ali se dizia, acusou o escravo de havêlos comido, referindo-lhe que a carta dissera contra ele. Mas o Índio (apesar dessa prova) negou candidamente o fato, maldizendo o papel como testemunha falsa e mentirosa.

"Em seguida, novamente enviado com igual Carga, e com uma Carta que dizia o Número certo de Figos que deviam ser entregues, ele de novo, segundo sua Prática precedente, devorou grande Parte deles ao longo do Caminho. Mas antes de tocá-los (para prevenir qualquer possível Acusação) Ele pegou a Carta e escondeu-a debaixo de uma Pedra, certo de que, se Ela não o visse comer os Figos, jamais poderia relatar o que não vira; mas ao ser, desta feita, acusado ainda mais gravemente do que antes, confessou a Culpa, admirando a Divindade do papel, e prometeu para o futuro, a maior Fidelidade em toda Tarefa de que fosse incumbido"".

Esse é apenas um relato que nos dá bem uma amostra, ainda que hoje a vislumbremos um tanto quanto pitorescamente, do que significou a nova linguagem em termos de afirmação e exercício de poder. Tal fato nos remete a filósofos como Platão, Aristóteles, Jean-Jacques Rousseau, Henry Bergson, dentre tantos outros, acerca da linguagem como ferramenta, técnica mediante a qual os homens distinguem-se dos outros animais. Aristóteles, por exemplo, afirma em seu escrito acerca da Política, que enquanto os outros animais possuem voz (phone), o homem possui a palavra $(\operatorname{logos})$. É com o uso e a articulação dessa palavra que o homem consegue constituir sua vida social, por meio de valores que lhes são caros porque com eles suas vidas são disciplinadas. É mediante a palavra que o homẹ̣ regula suas ações, ora para o bem, ora para o mal; ora sendo justo, ora sendo injusto. Por isso, o homem é o único animal político.

Platão legou-nos uma concepção da linguagem bastante peculiar e que nos dá a medida do poder que se exerce mediante o seu domínio e seu uso. Está em seu diálogo Fedro o conceito da linguagem como fharmakon. Com a linguagem, o homem socializa-se, faz política, relaciona-se com o seu mundo. Ou seja, para Platão, a linguagem pode ser um remédio, um medicamento, pois propicia o conhecimento. É mediante o diálogo que o homem descobre a sua medida, a sua ignorância e assim pode aprender com o outro. Mas, para ele, a

Comun. Inf., v. 6, n. 1, p.11-29, jan./jun. 2003 


\section{8}

linguagem pode se constituir também como veneno. Isso quando, por meio da sedução da linguagem, nos faz aceitar o engano, a falsidade, como verdadeiros. Por último, a linguagem pode ser também um cosmético quando mascara a verdade, maqueia os fatos. Ou seja, a linguagem tanto pode provocar o encanto, a sedução que induz ao erro, como também pode propiciar a comunicação e o conhecimento.

Platão, como sabemos, nunca caiu de moda. Mas a sua farmácia, para a análise que aqui buscamos empreender, parece estar mais atualizada e mais pertinente que qualquer outro conceito para entendermos o impasse em que se encontra a nossa sociedade informacional e globalizada, na entrada do século XXI.

\section{Um mundo sem espaço para os Davis}

Vivemos numa sociedade em rede. Estamos enredados uns pelos outros, cidadãos planetários, sobreviventes numa era de extremos e de incertezas contínuas. O tempo em que predomina o descontínuo e o caos numa sociedade midiática desterritorializada, que recebe um intenso bombardeio de informações. O tempo e o espaço foram comprimidos e o homem encontra-se no entre-lugar, em movimentos contínuos, cada vez mais preso às teias de um capitalismo que ressurge cada vez mais sedento de resultados. Tentando responder à questão (Como nossas vidas serão transformadas pelos novos meios de comunicação) que atormenta aqueles que se ocupam em pensar a nossa condição de seres planetários, Juan Luís Cerbrián escreveu uma obra bastante conhecida em nosso meio: Arede. Nessa obra, Cerbrián atribui à sociedade constituída através de nós que ligam um ponto a outro em diferentes e infinitas possibilidades de conexão, um poder até então nunca verificado por nenhum outro país, em qualquer tempo.

Na introdução de sua obra $A$ Rede, Juan Luís Cerbrián, à guisa de uma pergunta, elabora uma reflexão acerca desses impactos que inevitavelmente as tecnologias trazem em seus rastros, estabelecendo novos valores, novas formas relacionais entre os homens e dos homens com o mundo:

"Se as esperanças desmedidas e os temores incertos que a sociedade global da informação hoje nos provoca acabarão por se diluir como algodão doce, demonstrando-nos que nem toda inovação tecnológica supõe, necessariamente, uma mudança na civilização; ou, ao contrário, marcarão uma fronteira no processo de evolução do ser humano, um antes e um depois 9 ."

Comun. Inf., v. 6, n. 1, p.11-29, jan./jun. 2003 
Segundo Manuel Castells ${ }^{10}$, vivemos numa sociedade pós-industrial. Uma sociedade em que a informação é produto do processo produtivo. Vivemos de informação e em função da nossa capacidade de gerar, trocar informações e conhecimentos em quantidades gigantescas, em tempos ultravelozes, numa escala planetária. Neste novo panorama, as empresas são pressionadas, por uma concorrência cada vez mais competitiva e voraz, a tornarem-se megacorporações. Já não dá mais para as empresas ocuparem um só território, tomarem conta de um só mercado, vivendo eternamente em berço esplêndido, colhendo frutos e lucros sem qualquer tipo de ameaça aos trabalhos e aos dias felizes.

Castells enfatiza que nas duas últimas décadas tivemos o florescimento de uma nova economia. Uma economia que opera em escala global sob os influxos de uma imensa capacidade de se estar interligada ponto a ponto. As fronteiras foram diluídas, caíram as barreiras comerciais que os países impunham ao mercado externo à guisa de protegerem suas pouco competitivas empresas. Agora vivemos num mundo transformado em mercado, ou seja, um mundo disputado palmo a palmo, onde verdadeiras guerrilhas são travadas entre as empresas em busca de sobrevivência. $\mathrm{O}$ alvo é o consumidor. Um consumidor cada vez mais arredio, mais exigente, porque cada.vez mais informado acerca de seus direitos; um consumidor que busca ser sempre e sempre a distinção e o reconhecimento de suas individualidades. Um consumidor que deve ser sempre "paquerado" pelas empresas que se agigantam para sobreviver; empresas que têm cada vez mais fome de mercados, como bem o mostra Castells:

"Chamo-a [a nova economia] de informacional e global para identificar suas características fundamentais e diferenciadas e enfatizar sua interligação. É informacional porque a produtividade e a competitividade de unidades ou agentes nessa economia (sejam empresas, regiõès ou nações) dependem basicamente de sua capacidade de gerar, processar e aplicar de forma eficiente a informação baseada em conhecimentos. É global porque as principais atividades produtivas, o consumo e a circulação, assim como seus componentes (capital, trabalho, matéria-prima, administração, informação, tecnologia e mercados) estão organizados em escala global, diretamente ou mediante uma rede de conexões entre agentes econômicos. É informacional e global porque, sob novas condições históricas, a produtividade é gerada, e a concorrência é feita em uma rede global de interação ${ }^{11}$."

Comun. Inf., v. 6, n. 1, p.11-29, jan./jun. 2003 
Assim, numa sociedade em que as conexões são intensas e as economias em rede estão ligadas por laços de interdependência, as grandes corporações têm muito mais chances de sobreviver. Até porque - se se toma como parâmetro as análises dos especialistas -, são as gigantescas estruturas que conseguirão, desterritorializadamente, espraiarem-se pelo planeta com seus tentáculos poderosos, brigando por segmentos de mercado cada vez mais cobiçados pela concorrência.

\section{E o negócio da publicidade, como fica?}

Nestes tempos de economia informacional e globalizada, a publicidade, que se constituiu como uma atividade que tem como escopo vender serviços e comprar espaços publicitários para seus clientes anunciantes, mais do antes se viu obrigada a ir às compras. É preciso, pois, ir às compras para não ser comprado; é preciso incorporar para não ser sugado. É preciso crescer para não desaparecer! É preciso ganhar mercados. Mais que isso: é vital a estratégia de invadir outras arenas, constituir-se como uma fortaleza, imbuída de novas armas; armas que sejam mais eficientes, capazes de abater rapidamente $o$ "inimigo", que antes era um pacífico companheiro com quem se dividia fraternalmente fatias de um mercado ainda pouco exigente em termos de eficiência e qualidade. Óbvio que o negócio da propaganda sempre foi disputado, nunca foi fácil instalar a sua tenda e simplesmente fazer sucesso, crescer no mercado.

O fato é que, em comparação aos dias em que sobre-vivemos, aqueles tempos eram de pura fraternidade entre os concorrentes, já que o cenário atual aponta para o fato de que só os grandes sobreviverão. Acabaram-se os dias em que Davis poderiam sonhar em levar o gigante Golias ao chão. As armas são outras - os pequenos não têm acesso a elas - e o território não é mais aqui. A luta está sendo travada desterritorializadamente. A sociedade é planetária, o planeta é nosso chão comum. Há que disputá-lo, há que conquistá-lo dia a dia para garantir a própria sobrevivência:

"A indústria global da comunicação gravita em torno de
corporações capazes de operar, ao mesmo tempo, em ramos
correlatos ou cruzados, sem limites geográficos ou culturais.
Esse é um tempo de somatório de forças, das hegemonias
que se projetam a partir de movimentos sinuosos de estruturas

Comun. Inf., v. 6, n. 1, p.11-29, jan./jun. 2003 
transnacionais a multinacionais. Os eixos condutores são os capitais externos, movidos pelo apetite desmesurado por lucratividade e concentrados nas mãos de um número restrito de complexos empresariais, quase todos sediados nos Estados Unidos da América ${ }^{12}$."

O que forjou este modelo de ação econômica que substituiu o conceito de empresas por corporações, megacorporações? As flexibilizações e as desregulamentações dos mercados antes protegidos pelas políticas públicas, deram lugar a uma política de arraigada competitividade das empresas. As armas? Um forte domínio tecnológico e uma competente estrutura comunicacional em rede planetária. $\mathrm{O}$ mundo ficou pequeno à medida que os mercados locais ficaram encolhidos diante da capacidade de produção das gigantescas corporações. Essas megacorporações encontraram ou forjaram todo um panorama propício para que estendessem seus tentáculos a todo o planeta.

Alianças, compras, fusões, acordos operacionais. Esses são os termos a que nossos sentidos se habituaram, com a chegada das transnacionais. Recentemente, por ocasião da Bienal do Livro, assistimos ao "desembarque da armada espanhola" que veio às compras. De olho em nosso promissor mercado de livros, as editoras da terra de Cervantes passaram a assediar as nossas editoras.

$\mathrm{Na}$ avaliação de Robert McChersney, "o mercado de mídia gira em torno de cinco a oito conglomerados, com duas dezenas de empresas consideravelmente grandes ocupando os segmentos regionais e tendo acordo com um ou dois players"13. O mercado que mais cresce é o da mídia. Dentre os homens mais ricos do mundo, figuram os empresários da tecnologia digital, como Bill Gates, só para ficar nesse exemplo. Os mais ricos operam a partir do vale do silício. Prova disso é que, dentre as 500 maiores companhias do mundo, dez estão no ramo da multimídia. $\mathrm{Se}$, até bem pouco tempo atrás, supunha-se que as companhias, quando crescem, ganham mercados e produzem mais, abrem mais postos de trabalho, essa lógica não mais é verificada. Cada vez mais as companhias precisam de menos pessoas para operacionalizar as suas ações em busca da lucratividade. Elas demitem cada vez que têm uma leve ameaça à consolidação de suas metas de sustentabilidade, lucratividade e crescimento.

As corporações publicitárias não conseguem fugir à regra. Elas tiveram que se alinhar às novas exigências de uma economia planetária

Comun. Inf., v. 6, n. 1, p.11-29, jan./jun. 2003 


\section{2}

que não mais respeita barreiras territoriais. À custa de fusões, incorporações, as agências agigantam-se. Até mesmo os executivos das mega-agências não mais têm tranqüilas noites de sono. A disputa ocorre no andar de baixo e também no andar de cima, pois as grandes se devoram: "As gigantes estão engolindo grandes firmas, e não somente médias e pequenas. 'Não há mais concorrentes para os megagrupos, a não ser eles próprios`, sentencia The Wall Street Journal America's" ${ }^{\prime \prime}$.

Por isso, até mesmo os gigantes, os vitoriosos que estão no páreo comprando e esmagando os concorrentes, sentem o peso da responsabilidade de se manterem de pé, sobrevivendo num mercado repleto de esfinges devoradoras. $\mathrm{O}$ desenho desse palco de guerras em que se transformou o mundo, agora metamorfoseado de mercado, ganha cores e formas penumbrosas quando nos deparamos com $o$ desabafo de quem está por cima. Isso porque todos sabem que o tempo é de instabilidades e incertezas: 'Está cada vez mais doloroso sobreviver entre as gigantes', reconhece Martin Sorrell, presidente executivo do britânico WPP, um dos líderes mundiais de publicidade, com mais de 70 empresas coligadas em 92 países e lucro bruto superior a U\$ 800 milhões em 2000"15.

O que dizer das agências de publicidade nacionais? Os tentáculos das megacorporações publicitárias americanas e européias estenderamse em nosso território. Tudo começou com o caso MPM-Mafuz, Petrônio e Macedo. A maior agência brasileira, oriunda do mercado sulino, conquistou o mercado nacional consolidando-se a partir do momento em que suas operações foram concentradas em São Paulo. AMPM, que durante anos liderou o ranking de faturamento, foi também uma das primeiras a "entregar-se" à cobiça das megacorporações em busca de internacionalização e hegemonia. A MPM internacionalizouse, passando a se denominar MPM/LINTAS.

Também a DM9, originada na Bahia, acabou fundindo-se com a DDB; a Giovanni \& Associados acabou cedendo aos encantos da FCB. As nacionais compram as nacionais, que acabam sendo incorporadas pelas multinacionais. Esse processo revela a luta pela permanência no negócio. Quem ficar sozinho irá para a vala comum dos mortos $^{16}$. Algumas ainda resistem às investidas, como a lendária DPZ, de Duailib, Petit e Zaragoza, Agnelo Pacheco. Mas o meio sentencia: "é só uma questão de tempo. Elas cederão mais cedo ou mais tarde". Um caso típico é o verificado com Washington Olivetto.

Comun. Inf., v. 6, n. 1, p.11-29, jan./jun. 2003 
Ao sair da DPZ, ele abriu sua tenda sob os auspícios da suíça GGK. Parece ter sido essa apenas uma estratégia do nosso mais famoso publicitário que, mais uma vez, fez diferente das suas congêneres nacionais. Assim que ganhou fôlego, Olivetto emancipou-se da mãe GGK, tornando-se ela mesma uma multinacional, com as devidas proporções. Parece que numa tentativa de manter os nossos brios de independência e afirmação de soberania ante as multinacionais, Olivetto denominou sua bem-sucedida agência com o sugestivo nome de W/ Brasil.

\section{Propaganda online: publicitários offline?}

A nova concepção do business apóia-se em um novo formato de empresa, que é o que James Martin chama de Cybercorps ou corporações cibernéticas. São empresas virtuais, nas quais não existem mais áreas de atuação como contabilidade, produção, compras etc. $\mathrm{O}$ que domina são os sistemas de informação, funcionando numa base altamente informatizada. Ainformação passa a ser, portanto, um recurso tão importante quanto os recursos humanos, financeiros e tecnológicos. Os negócios são movidos por projetos e as pessoas se vinculam a tarefas (jobs). O emprego, tal como foi e ainda é concebido pela nossa tradição, segundo os analistas, tenderá a desaparecer, pois cada indivíduo poderá trabalhar para muitos empreendimentos. Com isso, as empresas estarão se fundindo, não apenas grandes incorporando pequenas, mas, principalmente, todas contra todas. E em pouco tempo - pode parecer loucura - não mais teremos empresas e sim, redes corporativas. Nelas, cada tarefa será valorizada e tratada de forma cada vez mais individualizada.

Nicholas Negroponte, que ocupa a posição de Marshall McLuhan da era digital, desde sua obra Vida Digital ${ }^{17}$, vem reiterando que estamos em face de um novo universo, que não só vai alterar os negócios, como também a educação, estruturas bancárias e os meios de comunicação, propaganda e varejo. Vivemos agora numa cultura cyber, na qual os átomos perdem importância para os bytes, à medida que $\mathrm{o}$ preconizado mundo-mensagem de McLuhan tornou-se mesmo realidade. Negroponte aponta-nos um panorama em que a emergência por novos espaços e novos mercados transformou conceitos e estratégias econômicas, forçando um novo modus vivendi, um novo modus operandi. Tudo agora mudou de escala. Tudo é muito rápido. O meio deixou de ser a mensagem, porque a mensagem determina,

Comun. Inf., v. 6, n. 1, p.11-29, jan./jun. 2003 


\section{4}

modifica o meio a todo instante. Assim, os profissionais da Propaganda estão atordoados, não mais sabendo como jogar o jogo da nova economia. Talvez eles ainda não tenham se apercebido das promessas e dos perigos que as tecnologias digitais oferecem ao negócio. As regras são outras e a linguagem que os novos tempos requerem ainda está longe de ser plenamente dominada. Na Internet, em 1995 foram movimentados 33 milhões de dólares e para 1996 estavam previstos pelo menos 330 milhões. Com isso, muda-se também o tipo de atuação das agências.

Por ser ainda uma ciência nova, o Marketing Digital não vem com o "manual do usuário". Também os números e previsões são muito mais difíceis de ser obtidos, pois o sistema de coleta dessas informações é ainda incipiente e as novas tendências não nascem mais das grandes empresas (até onde podemos acompanhar seu desenvolvimento), mas sim de qualquer lugar do mundo criado por um ilustre desconhecido. Anunciantes americanos poderiam estar veiculando mais na Web, não fosse a falta de estatísticas padronizadas. O que fazer? Cada agência tem a sua própria opinião, mas nenhuma delas consegue formular uma hipótese mais segura.

É mais fácil acertar na loteria do que anunciar na Internet, a julgar pelo que dizem as agências americanas. Nem as próprias agências concordam entre si em relação ao que deve ser feito, e a dificuldade está em mensurar resultados que dêem mais segurança aos anunciantes. Mas as mudanças de paradigmas nos negócios vêm ocorrendo há bem mais tempo. Pelo menos na terra dos inventores do marketing moderno, os Estados Unidos, as agências de publicidade sentiram-se acuadas ante as novas exigências do mercado dos anos 90 .

$\mathrm{O}$ terror vivido pelos publicitários da Madison Avenue, relata Martin Mayer ${ }^{18}$, pode ser detectado à luz do exemplo de Peter Georgescu, presidente da maior agência americana de então, a Young \& Rubicam. Em 1988, como presidente do comitê do "Valor da Publicidade" na American Association of Advertising Agencies, ponderou junto a Mayer que "a indústria da publicidade estava com enormes problemas, em grande parte porque os gastos em promoções em curto prazo estavam substituindo os orçamentos para a publicidade em todas as grandes companhias de produtos embalados"19. A estratégia para a superação de um impasse de tal envergadura, na visão de Mayer, estaria fundamentada em três pontos, quais sejam: construir marcas como o valor de maior bem, a busca obssessiva pela competitividade

Comun. Inf., v. 6, n. 1, p.11-29, jan./jun. 2003 
e, finalmente, os americanos deveriam evitar a competitividade de mercadorias industrializadas com os países emergentes. Naquela altura, percebeu-se que disputar mercado com produtos de linhas de montagens de países como Cingapura, Coréia, Taiwan, Tailândia e Brasil equivaleria a buscar a via do suicídio econômico.

Assim, ao construirem marcas e vendê-las como valores essenciais ao homem ocidental, os americanos, via intensa capacidade de gerar e transmitir informação ao resto do mundo, venderam o seu way of life como uma vida de benesses. Desta feita, os americanos nos fizeram acreditar que o paraíso era lá, mas nós poderíamos ter um pedacinho desse paraíso em nosso próprio lugar. Bastava usarmos os seus produtos tecnológicos. Quanto aos publicitários, eles estão preparados para enfrentar a nova mídia? A julgar pelo entendimento do jornalista e publicitário Pyr Marcondes, não! Enfático em seu artigo "Vai ter filminho, oba!'”20, Marcondes, em tom irônico, como que para tocar os brios dos publicitários reticentes com a nova ferramenta, a nova linguagem, diz:

"Tenho tido a feliz oportunidade de ser convidado a dar algumas palestras para o setor de propaganda sobre a web. Na platéia tem de tudo: mídias, planejadores, atendimento, estudantes... mas ninguém da criação.(...) A presença é frugal. Em alguns casos, inexistente. Aí, a eloqüente ausência fica sendo a melhor resposta à pergunta sobre o preparo do criativo brasileiro diante o mundo online. Insisto que é a média e que há exceções à regra, mas, analisando a categoria enquanto tal, o cenário é mais ou menos triste ${ }^{21}$."

Ao final de seu artigo, Marcondes salienta que o publicitário que for esperto, atento, não perderá mais esse bonde da comunicação online: a broadband, a banda larga da internet 2 , que possibilitará a fórmula dos filminhos de 30 segundos com que os criativos de todo o mundo fizeram fama e dinheiro.

Termino narrando uma dolorosa experiência vivenciada por mim no ano de 1999. Tão marcante foi para mim esse acontecimento que, acredito, foi ele mesmo o mote maior para a abordagem das questões a que nos propusemos. Trata-se da inadequação do publicitário aos novos meios midiáticos. Trabalhei ao longo de mais de duas décadas em agências de publicidade no mercado goiano, com uma passagem pelo mercado paulista. Nessa atividade, na função de redator e depois

Comun. Inf., v. 6, n. 1, p.11-29, jan./jun. 2003 


\section{6}

como diretor de criação, criei filhos, fiz amigos. Chega um tempo, contudo, em que fazemos uma autocrítica. O que mais quero da vida? Estou feliz? Que sonhos deixei de realizar?

Assim, partindo em busca de novas realizações, procurei investir em minha formação acadêmica, já que o feito de chegar à graduação estava realizado. Fui para o mestrado. Cumprida a meta, debandeime, no ano de 1995, para o Rio de Janeiro em busca do doutoramento na PUC. Lembro-me que, à época, as agências goianas começavam a dotar suas estruturas com novas ferramentas. Os computadores, os velhos Mach, despertavam a curiosidade e a desconfiança entre meus companheiros de agência. Trabalhávamos - e éramos felizes! - em duplas, o redator com sua velha Olivetti, o diretor de arte encastelado em sua prancheta de guerra. Letraset, estiletes, réguas, aerógrafo, fotocomposição, dentre outros apetrechos, constituíam nossas ferramentas de trabalho.

Cumprida a missão acadêmica no Rio, voltei para a agência dos velhos tempos. Fui dirigir a criação. O mobiliário já era outro. No lugar das pranchetas e das Olivettis, estavam as work station, as estações de trabalho mal - e - mal operadas por jovens aspirantes a publicitários. Onde estavam os velhos companheiros que tão bem manejavam o nanquim e a lapiseira para criar o lay-out à mão? Estavam fora do jogo. Tentei integrar alguns velhos companheiros às novas ferramentas. Inútil tentativa, pois a resistência às novas linguagens estava dentro deles mesmos. Perdi de vista tão bons amigos. Agora, vivendo mais o ambiente acadêmico que o afã e a correria de uma agência de publicidade, posso ver meus companheiros vivendo como os prisioneiros do "Mito da Caverna" a que se refere Platão: no mundo das sombras. Mesmo quando sobem à superfície, têm dificuldade de encarar e entender a realidade que os cega.

Para insistir nessa peleja, com a consciência de que habitamos o instável, de que somos filhos do caos e da intempérie, é possível agarrar-se, ainda, a alguma esperança? Fiquemos com a perspectiva poética apontada por Carlos Drummond de Andrade em seu Sentimento do mundo e com a esperança de que o caminho possa ser percorrido de Mãos dadas: 
Não serei o poeta de um mundo caduco.

Também não cantarei o mundo futuro.

Estou preso à vida e olho meus companheiros.

Estão taciturnos, mas nutrem grandes esperanças.

Entre eles, considero a enorme realidade.

$O$ presente é tão grande, não nos afastemos.

Não nos afastemos muito, vamos de mãos dadas...

\section{Abstract}

The growth of new markets and the transformation of economic concepts and strategies lead to new modus vivendi and new modus operandi in many aspects os life. The new communication technologies change the propaganda business and some questions must be answered: are the propaganda and publicity professionals able to face these challenges?

Key words: communicaiton technologies, marketing, propaganda.

\section{Notas}

' VEIGA, J. J., 1968:93-97.

${ }^{2}$ LÉVY, Pierre. 1999.

${ }^{3}$ Idem: 21 .

${ }^{4}$ Idem: 22. Aqui, Pierre Lévy nos indica uma pista para um aprofundamento da questão, ainda com Régis Debray, com o seu Cours de médiologie générale, Paris, Gallimard, 1991, Transmettre, Paris, Odile Jacob, 1997, e a bela revista Lé cahiers de Médiologie.

${ }^{5}$ Idem: 23 .

${ }^{6}$ Idem: 22.

${ }^{7}$ Havelock, Eric. A. 1996: 25.

${ }^{8}$ Apud: ECO, Umberto: 1995.

${ }^{9}$ CERBRIÁN, J. L. .: 31 .

${ }^{10}$ CASTELLS, Manuel: 1999.;

"Idem: 87.

${ }^{12}$ MORAES, Dênis: 2001, 13.

${ }^{13}$ Idem, 19.

${ }^{14}$ Idem, 45.

${ }^{15}$ Apud, MORAES, Dênis, 2001, 45.

${ }^{16}$ Não nos alongaremos na descrição do processo de fusões e incorporações das agências publicitárias brasileiras pelo simples fato de que a obra de Dênis Moraes nos apresenta-nos esse cenário em sua obra recentemente publicada, à qual recorremos na pesquisa, e que se encontra na bibliografia deste trabalho. ${ }^{17}$ NEGROPONTE, Nicholas: 1997.

Comun. Inf., v. 6, n. 1, p.11-29, jan./jun. 2003 


\section{8}

${ }^{18}$ MAYER, Martim: 1991.

${ }^{19}$ Idem: 12.

${ }^{20}$ In: Meio digital: revista na era da internet: 2000, 4.

${ }^{21}$ Idem, ibidem.

\section{Referências}

ALIEZ, Éric. Deleuze-Filosofia Virtual. Trad.: Heloísa B. S. Rocha. São Paulo: Ed. 34 Letras, 1996.

CANCLINI, Nestor García. Consumidores e cidadãos: conflitos multiculturais da globalização. $3^{\mathrm{a}}$. Ed. Rio de Janeiro: Editora UFRJ, 1997

CASTELLS, Manuel. A sociedade em rede. 3 vols. $4^{\mathrm{a}}$ ed. Trad. de Roneide Venancio Majer, com a colaboração de Klauss Brandini Gerhardt. Prefácio de Fernando Henrique Cardoso. São Paulo: Paz e Terra, 2000.

CEBRIAN, Juan Luís. A rede: como nossas vidas serão transformadas pelos novos meios de comunicação. Trad.: Lauro Machado Coelho. São Paulo: Summus, 1999

CHLEBA, Márcio. Marketing digital: novas tecnologias \& novos modelos de negócio. São Paulo: Futura, 1999.

ECO, Umberto. Os limites da interpretação. Trad. Pérola de Carvalho. São Paulo: Ed. Perspectiva, 1995.

HAVELOCK, Eric. A . A revolução da escrita na Grécia e suas conseqüências culturais. Trad. Ordep José Serra.São Paulo: Editora da Universidade Estadual Paulista/Rio de Janeiro: Ed. Paz e Terra., 1996.

LÉVY, Pierre. As tecnologias da inteligência: o futuro do pensamento na era da informática. Trad. Carlos Irineu da Costa Rio de Janeiro: Ed. 34 Letras, 1993. . O que é virtual? Trad.: Paulo Neves. Rio de Janeiro: Ed. 34 Letras, 1997. . Cibercultura. Trad. de Carlos Irineu da Costa. São Paulo: Ed. 34, 1999. . A conexão planetária: o mercado, o ciberespaço, a consciência. Trad. Maria Lúcia Homem e Ronald Entler. São Paulo: Editora 34, 2001.

LEÃO, Lúcia. O labirinto da hipermídia: arquitetura e navegação no ciberespaço. São Paulo: Iluminuras, 1999.

MAYER, Martim. Afinal, o que aconteceu (e o que acontecerá) à Madison Avenue? - A publicidade nos anos 90. Trad. Alice Bittencourt e Tânia Posselt. São Paulo: Ed. Ortiz/Gazeta Mercantil, 1991.

MCLUHAN, Marshall. Os meios de comunicação como extensões do homem (understanding media). Trad.: Décio Pignatari. São Paulo: Editora Cultrix, s/d. MORAES, Dênis. O concreto e o virtual: mídia, cultura e tecnologia. Rio de Janeiro: DP\&A Editora, 2001.

MORIN, Edgar [et alli]. Para navegar no século XXI. Organizadores: Francisco Menezes Martins e Juremir Machado da Silva. RGS: EDIPUCRS/Editora Sulina, 1999.

Comun. Inf., v. 6, n. 1, p.11-29, jan./jun. 2003 
MOTA, Regina. "Tecnologia e informação". In.: Múltiplos olhares. Dayrell, Juarez (org.) Belo Horizonte: UFMG, 1996.

NEGROPONTE, Nicholas. A Vida digital. Trad. de Sérgio Tellaroli. São Paulo:

Cia das Letras, 1997.

PINHO, J. B. . Publicidade e vendas na internet: técnicas e estratégias. São Paulo: Summus Editorial, 2000.

RAMONET, Ignacio. A tirania da Comunicação. Trad.: Lúcia Mathilde Endllich Oth. Petrópolis/RJ: Vozes, 1999.

VEIGA, José J. A máquina extraviada. Rio de Janeiro: Ed. Prelo, 1968.

Comun. Inf., v. 6, n. 1, p.11-29, jan./jun. 2003 